\title{
Specific Coeliac Disease Antibodies and Microenteropathy
}

\author{
Mohammad Rostami Nejad and Mohammad Reza Zali \\ Celiac Disease Department, \\ Research Institute of Gastroenterology and Liver Disease, \\ Shahid Beheshti University of Medical Sciences, Tehran,
}

Iran

\section{Introduction}

Coeliac disease and dyspepsia are common conditions, and consume considerable resources in both investigation and treatment. In the last years, considerable changes in epidemiology of Coeliac disease (CD) have been observed. Recently several studies have been published on the prevalence and importance of CD in Iran and showed that 1 out of 166 healthy Iranian blood donors are affected by CD (1).

A marked increase in CD prevalence and incidence especially the gluten sensitivity with milder enteropathy has been reported, $(1,2)$ which can be at least partially explained by both the development of more sensitive serological tests and a high degree of disease suspicion $(3,4)$. The variability of in particular clinical (5) and histological aspects of CD may face the clinician often with uncertainty as some of the features might not quite fit in the diagnostic models in current guidelines (2).

Related malabsorptive symptoms, such as weight loss, diarrhea/steatorrhea and abdominal distension may not be necessarily observed in many CD (6). Atypical forms of CD have increased considerably (7) and the presence of dyspepsia as a unique symptom has been frequently attributed to $C D(8)$. In classical CD with prominent malabsorptive features, dyspepsia may be one of the symptoms. It has been reported that the frequency of $\mathrm{CD}$ in people with dyspeptic complaints is $1.1-3 \%$, which is two to nine times higher than in the general population around the world $(6,8-12)$. Anti-endomysial antibodies (EmA) were confirmed to be less sensitive than IgA tTG antibodies, although at present, human recombinant tissue transglutaminase (tTG) antibodies of IgA class are considered the most sensitive marker (8-11). Moreover, a new serological test that is, antibodies to deamidated gliadin peptides (DGP) - has been proposed as a screening test for CD, since many retrospective and perspective studies showed a very high diagnostic accuracy of this immune marker. AGA were the first serological markers routinely used for CD screening, allowing the identification of at-risk-patients for gluten-sensitive enteropathy, but at present their importance is only historical, since their predictive value is quite significantly lower than that of EmA and tTG antibodies. The sensitivity and specificity of tTG IgA is in the 93\% to $97 \%$ range and, therefore, they represent the first-choice test for screening asymptomatic 
people like dyspeptic patients and for ruling out $\mathrm{CD}$ in symptomatic patients with a low pretest probability for CD (9).

In the present study we described the prevalence of gluten sensitive enteropathy in dyspeptic patients and compare the value of serology with histology in diagnosing CD.

\section{Method}

\subsection{Patients and methods}

Between November 2007 and October 2008, 5732 patients aged 15 years or more attended the Gastroenterology section of the Taleghani Hospital of Tehran, Iran. Four hundred and seven patients (193 men and 214 women) with dyspepsia were prospectively studied. The study was approved by the institutional ethics committees of Research center for gastroenterology and liver disease, Shahid Beheshti University of Medical sciences, and all participants signed a written informed consent.

Individuals were considered dyspeptic if they complained of persistent pain or uneasiness in the upper abdomen. Upper GI endoscopies were performed in these patients to diagnose common causes of dyspepsia including esophagitis, peptic ulcers, duodenitis and cancer. In addition, $\mathrm{CD}$ was identified by histological alterations characteristic of gluten sensitive enteropathy and by consistent CD serology.

Gastric biopsies were obtained for H.pylori detection and biopsies from the second part of the duodenum for histological processing. Histological diagnosis of $\mathrm{CD}$ was based on the presence of intraepithelial lymphocytes, crypts hyperplasia and/or villi atrophy. Biopsy results were classified as absence of CD (Marsh 0) or suggestive of CD (Marsh I to IIIC), according to Marsh criteria (13) and subsequently modified by Rostami et al. (14). The histological specimens were examined by two pathologists who did not know the endoscopic results and clinical history of the patients.

The optical density readings on enzyme-linked immunosorbent assay (ELISA) of 407 patients were analyzed for IgA class human antitissue transglutaminase (tTG) antibody and total serum IgA values according to the manufacturer's instructions (15). Determinations of IgA tTGA antibody were carried out using a commercially available kit (AESKULISA tTG, Germany). According to standardized methods, when a value higher than $15.0 \mathrm{U} / \mathrm{ml}$ was recorded, the result was considered positive. Total serum IgA values were measured by an immunoturbidometric assay (Pars Azmoon, Iran) and serum levels below 70 U/L were considered indicative of IgA deficiency. Those with IgA deficiency were tested with Immunoglobulin G (IgG) tTGG by an ELISA method, and using the commercially available kit (AESKULISA tTGG, Germany).

Serological data were correlated to the endoscopic results and to the histological pattern observed in the small intestine. All patients with confirmed CD diagnosis were treated with a gluten free diet and followed.

\subsection{Statistical analysis}

Statistical analysis was performed using SPSS software, version 13.5. Descriptive variables such as mean, median and standard deviation were determined. Chi-square $\left(\chi^{2}\right)$ test was performed to find out the association between $\mathrm{CD}$ and risk factors. 


\section{Results}

The mean age of the patients was 36.1 years. The gastroenterology symptoms in the subjects were: $78 \%$ abdominal pain, $70 \%$ bloating, $58 \%$ heart burn, $46 \%$ early satiety, $32 \%$ nausea, $32 \%$ flatulence, $31 \%$ weight loss and $22 \%$ anorexia. Recurrent abdominal pain, heart burn and bloating were present in $60 \%, 45 \%$ and $31 \%$ of the patients respectively.

H.pylori was detected in $90.5 \%$ cases. There were 26 cases with enteropathy (12 Marsh I, 4 Marsh II, 2 Marsh IIIa, 6 Marsh IIIb and 2 Marsh IIIc). Four of 407 dyspeptic patients were IgA deficient and all of them were negative for IgG tTG. Thirty three (8.1\%) of the 407 patients tested had tTGA level more than $15 \mathrm{u} / \mathrm{ml}$ and considered as tTGA positive. Twenty three of 33 seropositive had normal small bowel mucosa.

The demographic, histologic and serologic characteristics of 33 patients with serology positive and 26 with abnormal histology are shown in table 1. In 10 of 33 tTGA positive patients $\mathrm{CD}$ was confirmed by histology analysis of the intestinal biopsy samples, giving a prevalence of CD of $2.45 \%$. Five of these 10 coeliac patients were Marsh IIIa-c followed by 3 Marsh I and 2 Marsh II. The highest rate of histological abnormalites and of CD seropositivity was found in the age cathegories of 21-30 years and 10-20 years respectively.

\begin{tabular}{|c|c|c|c|c|c|c|c|c|c|c|c|c|c|c|}
\hline \multirow[b]{2}{*}{ subjects } & \multirow[b]{2}{*}{$\begin{array}{l}\text { no. of } \\
\text { cases }\end{array}$} & \multirow[b]{2}{*}{$\begin{array}{c}\text { Mean } \\
\text { age }\end{array}$} & \multicolumn{2}{|c|}{ gender } & \multicolumn{8}{|c|}{ GI symptoms } & \multirow[b]{2}{*}{$\mathrm{HP}$} & \multirow[b]{2}{*}{$\mathrm{CD}$} \\
\hline & & & M & $\mathrm{F}$ & $\mathrm{AP}$ & $\mathrm{AN}$ & WL & NA & HB & ES & FL & $\mathrm{BL}$ & & \\
\hline $\begin{array}{c}\text { Abnormal } \\
\text { histology } \\
\text { patients }\end{array}$ & 26 & 37.9 & 11 & 15 & 18 & 6 & 11 & 5 & 14 & 8 & 7 & 12 & 21 & 10 \\
\hline $\begin{array}{c}\text { Seropositive } \\
\text { patients }\end{array}$ & 33 & 42.6 & 13 & 20 & 25 & 8 & 9 & 9 & 10 & 9 & 7 & 15 & 26 & 10 \\
\hline
\end{tabular}

AP; abdominal discomfort, AN; anorexia, WL; weight loss, NA; nausea, HB; heart burn, Early satiety, FL; flatulence, BL; bloating, HP; Helicobacter pylori, CD; Coeliac disease

Table 1. Clinical and laboratory features of seropositive patients

\section{Discussion}

Dyspepsia is a highly prevalent and heterogeneous disorder (16). We know that damages in gluten sensitivity are not confined to the small intestine (17) and no every gluten sensitive patients develop severe mucosal small bowel abnormality. Several studies have demonstrated that continues exposure to gluten may damage the structure and function of the gastric mucosa in gluten-sensitive patients $(18,19)$. Other surveys indicate that approximately $20 \%$ of patients with dyspeptic symptoms have erosive esophagitis, $20 \%$ are estimated to have endoscopy-negative reflux disease, $10 \%$ have peptic ulcer, $2 \%$ have Barrett esophagus (20) and the results of the present study suggest that at least 2-3\% coeliac disease with histology confirmation could be added to the list. However, the proportion of gluten related dyspepsia seems to be even higher (serology $>8 \%$ ) and hence gluten sensitivity might be a major etiology for dyspepsia. 
The most important identifiable causes underlying dyspeptic symptoms in our study group were duodenitis (13\%), gastritis (12\%), esophagitis (9\%) and peptic ulcer disease in $10 \%$ malignancies of the upper gastrointestinal tract were not found. Approximately $60 \%$ of patients with dyspepsia showed no abnormality in their mucosa but the majorities were positive for H.pylori.

A significant number ( $8 \%$ ) of our cohort with dyspepsia had positive serology for $\mathrm{CD}$. The large number with positive tTG in this study (in total 33 tTG positive which 23/33 had normal histology) would suggest that dyspepsia might represent a cardinal sign and a prevalent mod of presentation for gluten sensitivity. We found that anti-tTG IgA antibodies were highly specific but poorly sensitive for detecting severe villous atrophy in coeliac patients under a gluten free diet.

Immunoglobulin A (IgA), anti-endomysial antibodies (IgA EMA-ab) and IgA anti-tTG antibodies (IgA tTG-ab) are in close correlation in untreated as well as treated coeliac (fig 1) $(21,22)$. It is important to note that serology (EMA/tTGA) is a far more specific marker for atypical CD compared to microenteropathy (Marsh I-II) which seems to have a non-specific nature (23). In other word the specificity of serology for CD seems to be close to $99 \%$ in many studies (24). This is in contrast to histology that would have a non-specific value especially in cases with milder enteropathy (microscopic enteritis, Marsh 0-II). Obviously histology could represent the gold standard for CD diagnosis only in cases with severe mucosal abnormality (Marsh IIIa-c). Since tTG autoantibodies have a far higher specificity $(>98-100 \%)$ for CD compared to a milder enteropathy, we might consider a higher prevalence $( \pm 8 \%)$ for $C D$ in dyspeptic patients $(25,26)$. Testing for tTG antibodies is the cheapest and most accurate option, as the EMA method used to detect endomysial antibodies is subjective and uses expensive tissue of monkey oesophagus or umbilical cord as the substrate. When there is a low suspicion of $C D$, serological testing should be done as a high-specificity rule-in test, but when there is a high suspicion of CD, HLA typing as a highsensitivity rule-out test would be useful. This strategy might be helpful in encouraging health professionals to use serology because the index of suspicion is generally low for atypical presentation. Perhaps performing HLA typing in seronegatives would give some more degree of reassurance in ruling it out.

Recent studies has clearly emphasized that, while IgA DGP antibodies do not add anything to the IgA tTG test, but IgG DGP antibodies are a relevant test for CD diagnosis and can identify the CD patients with IgA deficiency (27). In this CD subgroup, IgG DGP antibodies should be preferred to IgG tTG antibodies, whose positivity, as generally acknowledged, is fairly less specific and indicative of CD than that of IgG DGP antibodies (fig 1).

We are aware that there is no a single perfect test to diagnose CD in its own. Histological abnormalities were found in $26(6.4 \%)$ of our patients. Despite high specificity of autoantibodies, this finding would provoke the discussion on seronegative cases and question the sensitivity of serological tests. Although, microenteropathy could be a result of any other intestinal disorder, from previous experience we learned those negative serological tests were less reliable in symptomatic cases presenting with a milder enteropathy (28- 30). 


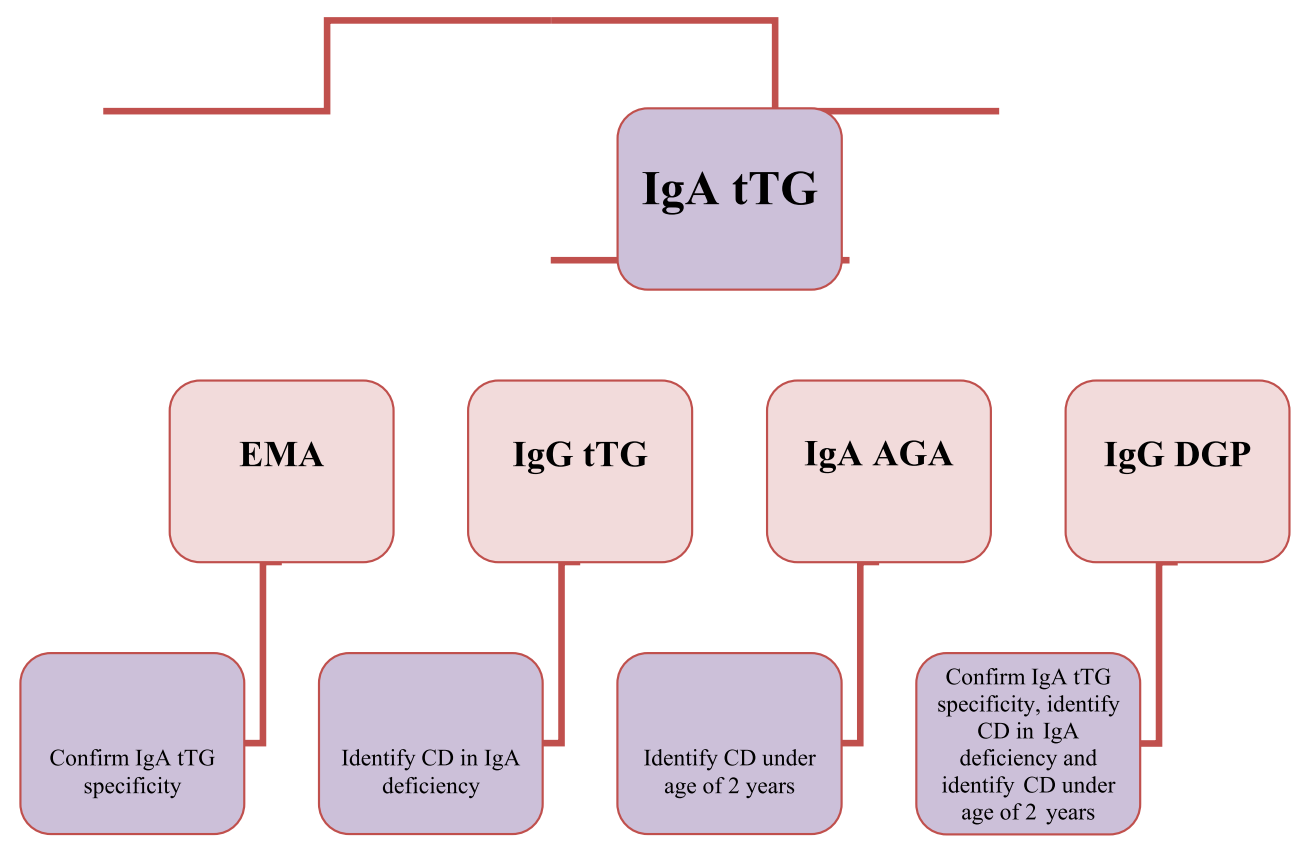

Fig. 1. Comparison between the present and new serological strategy for coeliac disease diagnosis 
Based on this evidence if we believe that specificity of serology (tTGA) is beyond $98 \%$ and if we also believe that seronegative cases presenting with milder enteropathy exist, we might be able to recognize that an even higher proportion $(>8 \%)$ of our CD patients might present with dyspepsia. In such cases in contrast to the high diagnostic value of severe enteropathy, microenteropathy obviously fails to represent the gold standard in diagnosis of gluten sensitivity as it is simply unreliable in its own. There is nothing against the fact that histology remains as an important component in diagnosis of GS but not as the gold standard at least in atypical cases with microenteropathy. Coeliac disease with flat mucosa based on which the gold standard was introduced $>50$ years ago is still a rare condition. It is time to recognize that for a good proportion of gluten sensitive cases histology is non-specific and hence the pathologist is unable to make the definite diagnosis in his own. Therefore, in conclusion, we suggest do not expect too much from histology and concentrate on clinical presentation and presence of autoantibodies as the diamond standard for diagnosis of CD. Future studies would be needed to assess whether dyspeptic patients presenting with positive antibodies and whatever histology would require gluten free diet?

\section{Reference}

[1] Rostami Nejad M, Rostami K, Emami MH, Zali MR, Malekzadeh R. Epidemiology of Celiac disease in Iran; A Review. Middle East Journal of Digestive Diseases 2011; 3(1): 74-77.

[2] Rostami K, Villanacci V. Microscopic enteritis: novel prospect in coeliac disease clinical and immuno-histogenesis. Evolution in diagnostic and treatment strategies. Dig Liver Dis 2009;41:245-52.

[3] Green PH, Fleischauer AT, Bhagat G, et al. Risk of malignancy in patients with celiac disease. Am J Med 2003;115:191-5.

[4] Green PH, Rostami K, Marsh MN. Diagnosis of coeliac disease. Best Pract Res Clin Gastroenterol 2005;19:389-400.

[5] Rostami Nejad M, Hogg-Kollars S, Ishaq S, Rostami K. Subclinical celiac disease and gluten sensitivity. Gastroenterol Hepatol Bed Bench. 2011;4(3): 102-108.

[6] Lima VM, Gandolfi L, Pires JAA, Pratesi R. Prevalence of Ccliac disease in dyspeptic patients. Arq Gastroenterol 2005; 42(3); 153-6

[7] Ciclitira PJ. AGA technical review on celiac sprue. American Gastroenterological Association practice guidelines. Gastroenterology 2001; 120:1526-40.

[8] Bardella MT,Minoli G, Ravizza D, Radaelli F, Velio P, Quatrini M, Bianchi PA, Conte D. Increased prevalence of Coeliac disease in patients with dyspepsia. Arch Intern Med 2000; 160:1489-1491

[9] Vivas S, Ruiz de Morales JM, Martinez J, Gonzalez MC, Martin S, Martin J, Cechini C, Olcoz JL. Human recombinant antitransglutaminase antibody testing is useful in the diagnosis of silent coeliac disease in a selected group of at-risk patients. Eur J Gastroenterol Hepatol 2003;15:479-83.

[10] Ozaslan E, Akkorlu S, Eskioglu E, Kayhan B. Prevalence of silent celiac disease in patients with dyspepsia. Dig Dis Sci. 2007; 52(3): 692-7 
[11] Altintas E, Senli MS, Sezgin O. Prevalence of celiac disease among dyspeptic patients: A community-based case-control study. Turk J Gastroenterol. 2008; 19(2): 81-84.

[12] Giangreco E, D'Agate C, Barbera C, Puzzo L, Aprile G, Naso P, et al. Prevalence of Coeliac disease in adult patients with refractory functional dyspepsia: Value of routine duodenal biopsy. World J Gastroenterol. 2008; 14(45): 6948-53.

[13] Marsh MN. Gluten, major histocompatibility complex, and the small intestine. A molecular and immunobiological approach to the spectrum of gluten sensitivity. Gastroenterology 1992; 102: 330-354.

[14] Rostami K, Kerckhaert J, Tiemessen R, von Blomberg BM, Meijer JW, Mulder CJ. Sensitivity of antiendomysium and antigliadin antibodies in untreated Coeliac disease: disappointing in clinical practice. Am J Gastroenterol 1999; 94: 888-94.

[15] Rostami Nejad M, Rostami K, Pourhoseingholi MA et al. Atypical Presentation is Dominant and Typical for Coeliac Disease. J Gastrointestin Liver Dis. 2009; 18 (3): 285-291.

[16] Talley NJ, Zinsmeister AR, Schleck CD, Melton LJ, 3rd. Dyspepsia and dyspepsia subgroups: a population-based study. Gastroenterology 1992; 102:1259-68.

[17] Diamanti A, Maino C, Niveloni S, Pedreira S, Vazquez H, Smecuol E, Fiorini A, Cabanne A, Bartellini MA, Kogan Z, Valero J, Maurino E, Bai JC. Characterization of gastric mucosal lesions in patients with Coeliac disease: a prospective controlled study. Am J Gastroenterol 1999; 94:1313-9.

[18] Locke GR, 3rd, Murray JA, Zinsmeister AR, Melton LJ, 3rd, Talley NJ. Coeliac disease serology in irritable bowel syndrome and dyspepsia: a population-based casecontrol study. Mayo Clin Proc 2004;79:476-82.

[19] Bardella MT, Minoli G, Ravizza D, Radaelli F, Velio P, Quatrini M, Bianchi PA, onte D. Increased prevalence of Coeliac disease in patients with dyspepsia. Arch Intern Med 2000;160:1489-91.

[20] Moayyedi P, Talley NJ, Fennerty MB, Vakil N. Can the clinical history distinguish between organic and functional dyspepsia? Jama 2006;295:1566-76.

[21] Amin M, Eckhardt T, Kapitza S, et al. Correlation between tissue transglutaminase antibodies and antiendomysium antibodies as diagnostic markers of coeliac disease. Clin Chim Acta 1999;282:219-25.

[22] Sulkanen S, Halttunen T, Laurila K, et al. Tissue transglutaminase autoantibody enzyme-linked immunosorbent assay in detecting celiac disease. Gastroenterology 1998;115: 1322-8.

[23] Sbarbati A, Valletta E, Bertini M, Cipolli M, Morroni M, Pinelli L, Tato L. Gluten sensitivity and 'normal' histology: is the intestinal mucosa really normal? Dig Liver Dis 2003;35:768-73.

[24] Abrams JA, Diamond B, Rotterdam H, et al. Seronegative coeliac disease: increased prevalence with lesser degrees of villous atrophy. Dig Dis Sci. 2004;49: 546-50.

[25] Hill PG, Holmes GK. Coeliac disease: a biopsy is not always necessary for diagnosis. Aliment Pharmacol Ther 2008;27:572-7.

[26] Ludvigsson JF, Brandt L, Montgomery SM. Symptoms and signs in individuals with serology positive for Coeliac disease but normal mucosa. BMC Gastroenterol 2009;9:57. 
[27] Volta U, Granito A, Parisi C, Fabbri A, Fiorini E, Piscaglia M, et al. Deamidated gliadin peptide antibodies as a routine test for Coeliac disease: a prospective analysis. J Clin Gastroenterol. 2010; 44(3):186-90.

[28] Diamanti A, Maino C, Niveloni S, Pedreira S, Vazquez H, Smecuol E, Fiorini A, Cabanne A, Bartellini MA, Kogan Z, Valero J, Maurino E, Bai JC. Characterization of gastric mucosal lesions in patients with celiac disease: a prospective controlled study. Am J Gastroenterol 1999;94:1313-9.

[29] Locke GR, Murray JA, Zinsmeister AR, Melton LJ, Talley NJ. Coeliac disease serology in irritable bowel syndrome and dyspepsia: a population-based case-control study. Mayo Clin Proc 2004;79:476-82.

[30] Tack J, Lee KJ. Pathophysiology and treatment of functional dyspepsia. J Clin Gastroenterol 2005;39:S211-6. 


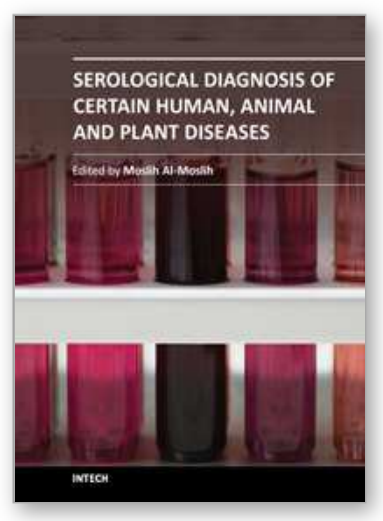

\section{Serological Diagnosis of Certain Human, Animal and Plant \\ Diseases}

Edited by Dr. Moslih Al-Moslih

ISBN 978-953-51-0370-7

Hard cover, 170 pages

Publisher InTech

Published online 21, March, 2012

Published in print edition March, 2012

This book explains the concept of serological methods used in laboratory diagnoses of certain bacteria, mycoplasmas, viruses in humans, animals and plants, certain parasitic agents as well as autoimmune disease. The authors present up-to-date information concerning the serological methods in laboratory diagnosis of such infectious diseases. Section one deals with the serological methods for bacteria. Section 2 deals with serological methods in human, animal and plant viruses. Section 3 is concerned with the serological laboratory diagnosis of echinococcus and human toxocariasis agents. The last section deals with serological laboratory methods in the diagnosis of coeliac disease.

\section{How to reference}

In order to correctly reference this scholarly work, feel free to copy and paste the following:

Mohammad Rostami Nejad and Mohammad Reza Zali (2012). Specific Coeliac Disease Antibodies and Microenteropathy, Serological Diagnosis of Certain Human, Animal and Plant Diseases, Dr. Moslih Al-Moslih (Ed.), ISBN: 978-953-51-0370-7, InTech, Available from: http://www.intechopen.com/books/serologicaldiagnosis-of-certain-human-animal-and-plant-diseases/specific-cd-antibodies-and-microenteropathy

\section{INTECH}

open science | open minds

\section{InTech Europe}

University Campus STeP Ri Slavka Krautzeka 83/A 51000 Rijeka, Croatia Phone: +385 (51) 770447 Fax: +385 (51) 686166 www.intechopen.com

\section{InTech China}

Unit 405, Office Block, Hotel Equatorial Shanghai No.65, Yan An Road (West), Shanghai, 200040, China 中国上海市延安西路65号上海国际贵都大饭店办公楼405单元 Phone: +86-21-62489820

Fax: +86-21-62489821 
(C) 2012 The Author(s). Licensee IntechOpen. This is an open access article distributed under the terms of the Creative Commons Attribution 3.0 License, which permits unrestricted use, distribution, and reproduction in any medium, provided the original work is properly cited. 